\title{
BERKOMUNIKASI EFEKTIF DENGAN KALIMAT EFEKTIF DALAM BAHASA INDONESIA
}

\author{
Parto \\ Program Studi Pendidikan dan Bahasa Sastra Indonesia \\ Email: parto.fkip@unej.ac.id
}

\begin{abstract}
The most effective communication media is language. However, not all uses of language can produce effective communication. Effective communication can only be done when there is an understanding between the communicator and the communicant. This means that language understanding between communicators and communicants is a demand in effective communication (Kemendikbud, 2013). In such languages it is necessary to use effective sentences. Therefore, in effective communication effective sentences. In other words, effective communication can only be achieved by using effective sentences. In this paper explained about communication, effective communication, and effective sentences in Indonesian.
\end{abstract}

Keywords: communication, effective communication, and effective sentences

\begin{abstract}
Abstrak
Media komunikasi yang paling efektif adalah bahasa. Namun demikian, tidak semua penggunaan bahasa dapat menghasilkan komunikasi yang efektif. Komunikasi efektif hanya dapat dilakukan manakala ada kesepahaman antara komunikator dan komunikan. Artinya bahwa kesepahaman bahasa antara komunikator dan komunikan merupakan tuntutan dalam komunikasi efektif (Kemendikbud, 2013). Dalam bahasa yang demikian diperlukan penggunaan kalimat-kalimat efektif. Oleh karena itu, dalam komunikasi efektif kalimat-kalimat efektif. Dengan kata lain, komunikasi efektif hanya dapat dicapai dengan menggunakan kalimat-kalimat efektif. Dalam tulisan ini dijelaskan perihal komunikasi, komunikasi efektif, serta kalimat efektif dalam bahasa Indonesia.
\end{abstract}

Kata kunci: komunikasi, komunikasi efektif, dan kalimat efektif

\section{Pendahuluan}

Manusia adalah makhluk individu dan sekaligus sebagai makhluk sosial. Sebagai makhluk sosial, manusia yang satu tidak bisa lepas dan saling membutuhkan dengan manusia yang lain. Dalam hubungan antarmanusia ini diperlukan bahasa sebagai media komunikasi karena bahasa memungkinkan manusia untuk bisa saling berhubungan dan berinteraksi soasial. Sehubungan dengan itu, Sobur (2016: 301) menegaskan bahwa bahasa memunyai fungsi yang amat penting bagi manusia, terutama sekali fungsi komunikatif. Artinya bahwa kehadiran bahasa sangat diperlukan dalam aktivitas berkomunikasi antarmanusia, bahkan hampir bisa dikatakan bahwa antara 
komunikasi dan bahasa bisa diumpamakan seperti dua sisi mata uang yang tidak bisa dipisahkan. Di mana ada aktivitas komunikasi di situ ada bahasa. Lebih tegas lagi, Sobur (2016: 3007) mengatakan bahwa komunikasi tanpa bahasa adalah sesuatu yang mustahil. Dalam hal ini, bahasa yang dimaksud bukan hanya bahasa verbal tetapi juga bahasa nonverbal sebagai penunjang bahasa verbal.

Dalam penggunaannya sebagai media komunikasi, bahasa menjadi sesuatu yang harus disikapi dengan hati-hati. Artinya, kalau menginginkan komunikasi kita bisa berlangsung dengan baik, kita harus pandai-pandai menggunakan bahasa. Kalau tidak, yang akan terjadi adalah kesalahpahaman (miss communication). Meskipun banyak faktor yang dapat menyebabkan kesalahpahaman, ketidaktepatan penggunaan bahasa merupakan faktor utama dan ini tampaknya sederhana tetapi justru yang sangat menentukan. Fishman (dalam Wibowo, 2001: 5) menegaskan bahwa berkomunikasi dengan bahasa sebetulnya bukan sekadar ditentukan oleh faktor linguistik atau bahasa itu sendiri, melainkan juga ditentukan oleh faktor nonlinguistik, seperti faktor sosial dan faktor situasional. Untuk itulah, diperlukan kehati-hatian dalam penggunaannya.
Sobur (2016: 306) menegaskan bahwa komunikasi itu sulit. Satu alasan mengapa orang mengalami kesukaran dalam proses yang sulit ini adalah karena bahasa yang dipergunakan tidak tepat. Penggunaan bahasa yang tidak tepat berarti kalimatkalimat yang digunakan dalam kegiatan berkomunikasi itu tidak efektif. Oleh sebab itu, agar proses komunikasi dapat berlangsung dengan baik dan efektif, bahasa yang kita gunakan hendaknya mengandung kalimat-kalimat yang efektif. Dari uraian latar belakang masalah di atas, dapatlah dirumuskan permasalahan sebagai berikut: (a) apakah komunikasi itu, (b) apa dan bagaimana komunikasi yang efektif itu, dan (c) apa dan bagaimana kalimat efektif itu digunakan dalam kegiatan berkomunikasi yang efektif?

\section{Komunikasi}

Istilah komunikasi secara umum dimaknai sebagai hubungan atau kegiatan yang berkaitan dengan masalah hubungan atau dimaknai pula sebagai hubungan antarmanusia baik individu maupun kelompok (Widjaja, 2000: 13). Di samping itu, masih banyak pengertian lain tentang istilah komunikasi yang dikemukakan para pakar ilmu komunikasi. Edward Depari (dalam Munandir dan Mangoendiprodjo, 1998: 8) memaknai komunikasi sebagai suatu proses penyampaian pesan melalui 
lambang tertentu yang bermakna dan dilakukan oleh komunikator kepada komunikan. Definisi lain dikemukakan oleh Charles H. Cooley (dalam Sunarjo dan Sunarjo) yaitu bahwa komunikasi merupakan suatu cara untuk mengadakan hubungan antarmanusia dan mengembangkan semua simbol dari pikiran-pikiran bersama dengan makna yang menyertainya secara leluasa serta memberikan respons tepat pada waktunya. Dari beberapa pendapat tentang pengertian komunikasi di atas dapat disimpulkan bahwa komunikasi adalah penyampaian informasi dan pengertian dari seseorang kepada orang lain. Komunikasi akan dapat berhasil manakala ada pemahaman yang sama, yaitu apabila kedua belah pihak (komunikator dan komunikan) saling memahami sesuatu yang dikomunikasikan. Yang demikian bukanlah berarti bahwa masing-masing pihak harus menyetujui sesuatu (informasi) tersebut, tetapi yang penting adalah masing-masing mempunyai pemahaman yang sama mengenai sesuatu (informasi) tersebut. Dalam keadaan seperti ini barulah dapat dikatakan komunikasi telah berlangsung dengan baik (komunikasi efektif).

Dari uraian di atas dapatlah dinyatakan bahwa dalam peristiwa komunikasi itu ada pernyataan manusia dan pernyataan tersebut dapat diungkapkan dengan kata-kata baik secara tertulis ataupun lisan. Di samping itu, dapat pula pernyataan tersebut disampaikan lewat isyarat atau simbolsimbol tertentu. Namun dari sekian banyak media yang dapat digunakan dalam kegiatan berkomunikasi, bahasa merupakan media komunikasi yang paling efektif, baik bahasa lisan maupun bahasa tulis.

\section{Komunikasi Efektif}

Manusia adalah makhluk sosial. Sebagai makhluk sosial, manusia memerlukan hubungan dengan manusia yang lain. Hubungan yang diharapkan tentunya hubungan yang baik, hubungan yang harmonis. Hubungan yang baik dan harmonis hanya dapat dicapai manakala ada interaksi dan komunikasi yang baik antara manusia yang satu dengan manusia yang lain. Komunikasi yang baik hanya dapat dicapai manakala adanya kesadaran saling memahami. Hal ini sebagaimana dikemukakan Widjaja (2000: 8) yang menyatakan bahwa hal yang harus dipenuhi untuk terjalinnya hubungan yang baik yaitu harus ada hubungan yang dilandasi saling memahami serta adanya pertukaran sesuatu yang bisa saling dimengerti. Jalinan yang baik itu 
memungkinkan manusia selalu ke dalam bentuk kalimat. Tidak dengan mengadakan hubungan yang berkembang dan mencerminkan keharmonisan.

Telah disebutkan di atas bahwa dari sekian banyak media komunikasi, bahasa merupakan media komunikasi yang paling efektif, baik bahasa lisan maupun bahasa tulis. Telah dikemukakan pula bahwa dalam penggunaannya sebagai media komunikasi, bahasa menjadi sesuatu yang harus disikapi dengan hati-hati. Artinya, kalau menginginkan komunikasi kita bisa berlangsung dengan baik dan efektif, kita harus pandai-pandai menggunakan bahasa. Kalau tidak, yang akan terjadi adalah kesalahpahaman (miss communication). Hal ini berarti bahwa kesalahpahaman terjadi karena bahasa yang dipergunakan tidak tepat. Penggunaan bahasa yang tidak tepat berarti kalimat-kalimat yang digunakan dalam kegiatan berkomunikasi itu tidak efektif. Oleh sebab itu, agar proses komunikasi dapat berlangsung dengan baik dan efektif, bahasa yang kita gunakan hendaknya mengandung kalimatkalimat yang efektif. Apa dan bagamana ihwal kalimat efektif, di bawah ini dipaparkan ihwal kalimat efektif selengkapnya.

\section{Kalimat Efektif}

Gagasan atau pikiran seseorang dalam kegiatan berkomunikasi harus dinyatakan mempelajari teori pun seseorang bisa saja membuat kalimat. Meskipun demikian, sudah benarkah kalimat yang digunakannya? Kebenaran sebuah kalimat menuntut persyaratan gramatikal. Artinya bahwa penyusunan kalimat haruslah memperhatikan kaidah-kaidah bahasa yang berlaku. Hal-hal yang harus diperhatikan dalam penyusunan kalimat adalah: (1) unsur yang harus ada dalam kalimat, (2) kaidah ejaan, dan (3) kaidah pemilihan diksi dalam kalimat (Akhadiah dkk., 1984/1985:1)

Kalimat yang disusun dengan benar secara gramatikal dan benar secara logikal akan dapat dengan mudah dipahami orang lain secara tepat. Kalimat seperti itu dapatlah disebut sebagai kalimat efektif. Sebuah kalimat efektif haruslah secara tepat dapat mewakili pikiran dan keinginan komunikator (penulis atau pembicara). Artinya bahwa kalimat efektif haruslah disusun dengan penuh kesadaran untuk mencapai kesepahaman.

Kebenaran gramatikal saja belum tentu menjamin efektivitas sebuah kalimat. Kalimat Wahai Ibu yang saya hormati, sudilah kiranya Ibu memberitahukan kepada saya berapakah gerangan harga satu kilogram telur ayam ini? secara gramatikal tidak akan disalahkan. Akan 
tetapi, hal itu dipandang tidak wajar manakala digunakan pada waktu berbelanja di pasar. Jadi, apakah sebenarnya batasan kalimat efektif itu?

Kalimat efektif dikenal dalam hubungan fungsi bahasa sebagai media komunikasi. Dalam hubungan ini, setiap kalimat terlibat dalam proses decoding dan encoding (penyampaian dan penerimaan). Sesuatu yang disampaikan dan diterima itu bisa berupa pemikiran, ide atau gagasan, pesan, pengertian, atau sebuah informasi. Sebuah kalimat disebut efektif manakala sanggup menciptakan proses penyampaian dan penerimaan itu berjalan sempurna. Kalimat efektif mampu membuat isi atau maksud yang disampaikannya itu tergambar dengan jelas dan lengkap dalam pikiran komunikan, persis seperti yang dipikirkan komunikator.

Dari paparan di atas, dapatlah dikatakan bahwa kalimat efektif adalah kalimat yang tepat mengenai sasaran, kalimat yang komunikatif, kalimat yang mudah dipahami, atau dalam batasan yang lebih panjang dapat dikatakan bahwa kalimat efektif adalah kalimat yang mudah dipahami dan pemahaman pendengar/pembaca (komunikan) sama persis seperti yang ada dalam pikiran pembicara/penulis (komunikator).
Dengan demikian, jelaslah bahwa kalimat efektif memerlukan beberapa persyaratan di samping persyaratan gramatikal/struktural. Persyaratanpersyaratan itu kemudian dapat dikatakan sebagai penanda atau ciri kalimat efektif. Dari berbagai literatur yang pernah dibaca, ada beberapa ciri kalimat efektif, yakni paling tidak sebagai berikut: (1) kelogisan, (2) kehematan, (3) kecermatan, (4) kesepadanan, (5) kepaduan, dan (6) keparalelan. Lebih rinci ciri-ciri kalimat efektif tersebut dapat diuraikan sebagai berikut.

\section{(1) Kelogisan}

Kelogisan dalam kalimat efektif dimaksudkan sebagai ide yang ada dalam kalimat itu dapat diterima akal sehat dan sesuai dengan ejaan yang berlaku. Kelogisan ini menjadi sangat penting dalam kalimat efektif. Kalimat yang benar secara gramatikal bisa menjadi tidak efektif tanpa adanya kelogisan. Misalnya seperti kalimat berikut ini.

(1) Pencuri berhasil ditangkap polisi. Secara gramatikal kalimat (1) di atas tidak salah. Akan tetapi, jika dilihat dari segi logika, kalimat itu terasa janggal dan tidak logis. Ketidaklogisan kalimat itu terletak pada kata berhasil karena pencuri yang ditangkap polisi tentu bukanlah suatu keberhasilan, melainkan justru merupakan 
kegagalan. Kalimat tersebut akan menjadi logis kalau diubah menjadi seperti di bawah ini.

(1a) Polisi berhasil menangkap pencuri. Atau

(1b) Pencuri berhasil melarikan diri dari kejaran polisi.

Contoh lain dari ketidaklogisan sebuah kalimat tampak pada kalimat bercetak miring di bawah ini.

(2) Acara berikutnya adalah sambutan-sambutan. Sambutan pertama akan disampaikan Rektor Universitas Muhammadiyah Jember.

Waktu dan tempat kami persilakan.

Sering kita jumpai pemandu acara dalam suatu kegiatan mengunakan kalimatkalimat semacam itu. Dalam contoh kalimat (2) yang terakhir seolah-olah waktu dan tempat-lah yang dipersilakan, padahal maksud kalimat tersebut adalah orang yang akan mengisi acara itulah yan dipersilakan. Kalimat tersebut akan menjadi logis kalau diubah menjadi seperti di bawah ini.

(2a) Yang terhormat Rektor Universitas Muhammadiyah Jember kami persilakan untuk memberikan kata sambutan sekaligus membuka acara ini.

Untuk bahasa tulis, kelogisan sebuah kalimat ditandai juga oleh penggunaan ejaan yang benar, yakni ejaan yang sesuai dengan Pedoman Umum Ejaan Bahasa Indonesia (PUEBI). Misalnya seperti kalimat-kalimat berikut ini.

(3) Sekalipun sering marah sekalipun saya tidak pernah memukul anak-anak saya.

Kalimat (3) di atas membingungkan dan sulit dipahami. Agar mudah dipahami dan diterima secara logika, kalimat itu sebaiknya ditulis sebagai berikut.

(3a) Sekalipun sering marah, sekali pun saya tidak pernah memukul anakanak saya.

\section{(2) Kehematan}

Kehematan dalam kalimat efektif dimaksudkan sebagai penghindaran penggunan kata, frasa, atau bentuk lain yang tidak perlu, sejauh tidak menyalahi kaidah tatabahasa dan tidak sampai mengubah makna. Upaya kita untuk melakukan penghematan dapat dilakukan dengan cara menghindari hal-hal sebagai berikut.

a. Pengulangan subjek yang tidak diperlukan. Misalnya:

(4) Karena saya datang agak terlambat, saya tidak dapat mengikuti acara pertama.

Kata saya yang berfungsi sebagai subjek pada anak kalimat tidak 
diperlukan karena subjek yang sama sudah disebutkan pada induk kalimatnya. Penyebutan kata saya pada anak kalimat di atas merupakan pemborosan kata yang sebaiknya dihindari. Akan lebih hemat kalau kalimat di atas diperbaiki sebagai berikut.

(4a) Karena saya datang agak terlambat, saya tidak dapat mengikuti acara pertama.

b. Penggunaan superordinat pada hiponimi kata. Misalnya:

(5) Gadis itu sedang memetik sekuntum bunga mawar warna merah.

(6) Indonesia merdeka pada hari Jumat tanggal 17 bulan Agustus tahun 1945 .

Kata mawar pada kalimat (5) sudah mengandung makna /bunga/ dan kata merah sudah mengandung makna /warna/. Demikian juga dalam kata Jumat, 17, Agustus, dan 1945 pada kalimat (6) terkandung makna /hari/, /tanggal/, /bulan/, dan /tahun/ tanpa disebutkan sekalipun. Dengan demikian, penyebutan kata bunga dan warna pada kalimat (5) dan kata hari, tanggal, bulan, dan tahun pada kalimat (6) menjadi mubazir karena merupakan pemborosan. Perbaikan kalimat-kalimat itu adalah sebagai berikut.

(5a) Gadis itu sedang memetik sekuntum mawar merah.

(6a) Indonesia merdeka pada Jumat, 17 Agustus 1945

Masih banyak kita jumpai kata berhiponim lain dalam bahasa Indonesia. Misalnya, kata burung sebagai superordinat dari kata kenari, kutilang, poksai, perkutut, beo, dan lain-lain, juga kata ikan sebagai superordinat dari kata kakap, koi, mujahir, bandeng, dan lain-lain.

c. Kesinoniman dalam satu kalimat

Banyak kata bersinonim dalam bahasa Indonesia. Kata naik besinonim dengan ke atas, kata hanya bersinonim dengan kata saja, kata sejak bersinonim dengan kata dari dan mulai, kata demi bersinonim dengan kata untuk, kata agar bersinonim dengan kata supaya, kata adalah dan merupakan, dan masih banyak lagi kata bersinonim lain dalam bahasa Indonesia yang kadang digunakan secara bersamaan dalam sebuah kalimat. Hal ini tentunya menjadi pemborosan. Perhatikan contoh kalimat di bawah ini.

(7) Dia berkuliah di sini mulai sejak dari satu tahun yang lalu.

(8) Kehadiran Anda adalah merupakan kehormatan bagi kami. 
Kalimat (7) dan (8) tidak efektif karena ada pemborosan kata, yaitu adanya kata mulai, sejak, dan dari yang merupakan kata bersinonim, demikian juga kata adalah dan merupakan. Kalimat-kalimat di atas akan lebih efektif (hemat) kalau diperbaiki menjadi seperti di bawah ini.

(7a) Dia berkuliah di sini sejak satu tahun yang lalu.

(8a) Kehadiran Anda merupakan kehormatan bagi kami.

d. Penjamakan kata-kata yang sudah berbentuk jamak. Misalnya:

(9) Semua hal-hal penting harus dicatat.

(10) Para tamu-tamu undangan sudah dipersilakan masuk.

Kata semua pada kalimat (9) dan kata para pada kalimat (10) sudah mengandung makna jamak. Oleh karena itu, tidak perlu lagi pengulangan yang bermakna jamak, sehingga kalimat-kalimat di atas dapat diperbaiki menjadi seperti di bawah ini.

(9a) Semua hal penting harus dicatat.

(10a) Para tamu undangan sudah dipersilakan masuk.

Kalimat-kalimat di atas dapat pula diperbaiki dengan cara mempertahankan bentuk perulangan sehingga menjadi seperti di bawah ini.

(9b) Hal-hal penting harus dicatat

(10b) Tamu-tamu undangan sudah dipersilakan masuk.

\section{(3) Kecermatan}

Kecermatan dalam menyusun kalimat efektif juga sangat diperlukan. Dalam hal ini kecermatan dimaknai tidak menimbulkan pengertian ganda dan tepat dalam pilihan kata. Perhatikan kalimat di bawah ini!

(11) Beliau adalah istri Pak Camat yang baru.

Kalimat (11) di atas mempunyai penafsiran ganda, yakni siapakah yang baru: apakah Pak Camat itu yang baru menikah atau baru dilantik menjadi camat? Untuk menghindari penafsiran ganda itu, perlu digunakan tanda hubung (-) seperti pada perbaikan kalimat di bawah ini.

(11a) Beliau adalah istri-Pak Camat yang baru. (bila yang baru adalah istrinya) atau

(11b) Beliau adalah istri Pak Camat-yang baru. (bila yang baru adalah jabatan camatnya)

Contoh ketepatan dalam pilihan kata dapat dilihat pada kalimat berikut ini!

(12) Tadi malam saya melihat pertunjukan wayang kulit semalam suntuk.

Pilihan kata melihat pada kalimat (12) kurang tepat, yang lebih tepat daripadanya adalah kata menonton, sehingga kalimat perbaikannya menjadi seperti kalimat di bawah ini. 
(12a) Tadi malam saya menonton pertunjukan wayang kulit semalam suntuk.

\section{(4) Kesepadanan}

Ciri keempat yang menandai keefektifan sebuah kalimat adalah kesepadanan. Kesepadanan dalam kalimat efektif dimaksudkan sebagai keseimbangan antara pikiran dengan struktur bahasa yang digunakan. Kesepadanan kalimat ini memiliki beberapa penanda sebagai berikut.

a. Kalimat yang sepadan memiliki subjek dan predikat yang jelas. Kejelasan subjek dan predikat suatu kalimat dapat dilakukan dengan menghindarkan penggunaan kata depan pada, kepada, bagi, di, untuk, dalam, dan sebagainya di depan subjek. Misalnya:

(13) Dalam buku itu membahas pemanfaatan tenaga surya.

Kata depan dalam pada kalimat di atas mengganggu kesepadanan sebuah kalimat karena menyebabkan kalimat itu tidak bersubjek. Kalimat tersebut akan lebih baik (sepadan) kalau kata depan dalam dihilangkan sehingga menjadi seperti di bawah ini.

(13a) Buku itu membahas pemanfaatan tenaga surya. b. Kalimat yang sepadan tidak memiliki subjek ganda. Misalnya sebagai berikut.

(14) Anak itu rambutnya keriting.

Kalimat di atas mempunyai subjek ganda: anak itu dan rambutnya. Kalimat itu akan lebih baik kalau diubah menjadi seperti di bawah ini. (14a) Anak itu berambut keriting.

Atau

(14b) Rambut anak itu keriting.

c. Penghubung intrakalimat (seperti sehingga, dan, atau, lalu, kemudian, sedangkan, bahkan, jika, dll.) tidak digunakan pada kalimat tunggal, misalnya sebagai berikut.

(15) Saya tidak bisa hadir dalam rapat itu. Sehingga saya tidak mengetahui keputusan hasil rapat.

Penggunaan kata sehingga dalam kalimat (15) tidaklah sepadan karena kata sehingga merupakan kata penghubung intrakalimatyang tidak bisa difungsikan sebagai penghubung antarkalimat. Perbaikan terhadap kalimat itu dapat dilakukan dengan dua cara, yaitu dengan menjadikan kalimat itu kalimat majemuk atau dengan mengganti kata penghubung intrakalimat menjadi ungkapan penghubung antarkalimat, seperti di bawah ini. 
(15a) Saya tidak bisa hadir dalam rapat itu, sehingga tidak mengetahui keputusan hasil rapat.;

(15b) Saya tidak bisa hadir dalam rapat itu. Oleh karena itu, saya tidak mengetahui keputusan hasil rapat.

\section{(5) Kepaduan}

Yang dimaksud dengan kepaduan dalam kalimat efektif ini adalah kepaduan pernyataan dalam kalimat itu sehingga informasi yang disampaikan tidak terpecah-pecah. Penanda-penanda kalimat yang padu dapat dipaparkan sebagai berikut.

a. Penanda pertama, kalimat yang padu tidak bertele-tele. Oleh karena itu, hindari penggunaan kalimat yang panjang dan berbelit-belit. Perhatikan kalimat berikut!

(16) Proses pemilihan dan penetapan bahasa kesatuan kita sangat mudah; pada mana, masingmasing perjuangan, di mana rakyat Indonesia yang tersebar dari Sabang sampai Merauke, yang senasib, seperjuangan serta satu cita-cita, maka karena kesadaran tadi, disertai pemikiran, maka rakyat Indonesia menetapkjan Bahasa
Nasional tersebut sebagai bahasa kesatuan.

Kita tentu bisa menilai bahwa kalimat (16) di atas terlalu panjang dan bertele-tele, sehingga susah untuk dipahami. Kalimat di atas akan mudah dipahami apabila strukturnya disederhanakan atau dipecah menjadi beberapa kalimat sehingga menjadi seperti berikut ini.

(16a) Proses pemilihan dan penetapan bahasa Indonesia sebagai bahasa kesatuan kita sangat mudah. Hal itu disebabkan oleh karena pada masa-masa perjuangan, rakyat Indonesia yang tersebar dari Sabang sampai Merauke merasakan senasib, seperjuangan serta satu cita-cita. Dengan kesadaran itu dan disertai pemikiran yang mantap, rakyat Indonesia menetapkjan bahasa Indonesia tersebut sebagai bahasa kesatuan.

b. Penanda kedua, kalimat yang padu menggunakan pola aspek + agen + verba secara tertib dalam kalimat-kalimat yang berpredikat persona. Misalnya sebagai berikut.

(17) Surat Anda saya sudah baca dan saya sudah pahami isinya. 
Kalimat (17) tidak menunjukkan kepaduan karena aspek terletak di antara agen dan verba. Kalimat itu akan menunjukkan kepaduan kalau disusun seperti di bawah ini (mengikuti pola aspek+agen+verba).

(17a) Surat Anda sudah saya baca dan sudah saya pahami isinya.

c. Penanda ketiga, kalimat yang padu tidak perlu menyisipkan sebuah kata antara predikat kata kerja transitif dan ojek penderita. Misalnya seperti yang terlihat pada kalimat berikut ini.

(18) Seluruh sivitas akademika harus memahami akan statuta kampusnya.

Penggunaan kata akan pada kalimat (18) tidak diperlukan karena kata kerja transitif memahami harus diikuti secara langsung oleh objek penderita statuta kampusnya. Perbaikan kalimat tersebut tampak pada kalimat (18a) berikut.

(18a) Seluruh sivitas akademika harus memahami statuta kampusnya.

Namun demikian, apabila ingin mempertahankan kata akan, hendaknya predikat kalimat itu diubah menjadi bentuk pasif sehinga menjadi seperti kalimat (18b) berikut ini.

(18b) Seluruh sivitas akademika harus paham akan statuta kampusnya.

\section{(6) Keparalelan}

Keparalelan dalam kalimat efektif dimaksudkan sebagai kesamaan atau kesejajaran bentuk kata yang digunakan dalam kalimat itu. Hal ini berarti bahwa kalau bentuk pertama menggunakan ungkapan nominal, bentuk kedua dan seterusnya hendaknya juga menggunakan bentuk yang sama, yaitu bentuk nominal; kalau yang pertama menggunakan bentuk verbal, hendaknya yang kedua dan seterusnya juga menggunakan bentuk yang sama, yaitu bentuk verbal. Misalnya:

(19) Tahap terakhir penyelesaian gedung itu adalah pengecatan tembok, memasang penerangan, menguji sistem pembagian air, dan pengaturan tata ruang..

Bila kita cermati, dalam kalimat (19) terdapat sebuah kata yang tidak sejajar dengan bentuk kata yang lainnya yang sama-sama mewakili fungsi pelengkap, yakni kata memasang dan menguji yang merupakan bentuk verbal, padahal yang lainnya berbentuk nominal. Kalimat tersebut akan lebih baik (menunjukkan adanya keparalelan) kalau diubah menjadi seperti kalimat (19a) di bawah ini.

(19a) Tahap terakhir penyelesaian gedung itu adalah pengecatan tembok, pemasangan penerangan, pengujian sistem 
pembagian air, dan pengaturan tata ruang.

Demikianlah paparan mengenai komunikasi efektif dengan menggunakan kalimat efektif dalam bahasa Indonesia.

\section{Simpulan}

Dari seluruh paparan pembahasan dalam tulisan ini, dapatlah disimpulkan sebagai berikut.

(1) Bahasa merupakan media komunikasi paling efektif yang tidak bisa lepas dari kehidupan manusia.

(2) Proses komunikasi hanya dapat berlangsung dengan baik dan efektif manakala bahasa yang digunakan mengandung kalimat-kalimat efektif.

(3) Kalimat efektif adalah kalimat yang mudah dipahami yaitu kalimat yang sanggup menimbulkan gagasan/perasaan yang sama tepatnya dalam pikiran komunikan (pendengar/pembaca) persis seperti yang dipikirkan komunikator (pembicara/penulis).

(4) Kalimat efektif tidak hanya benar secara gramatikal tetapi juga benar secara logikal, selain itu kalimat efektif harus komunikatif.

(5) Di samping persyaratan gramatikal, kalimat efektif masih menuntut sejumlah ciri/persyaratan yang lain, yaitu (1) kelogisan, (2) kehematan, (3) kecermatan, (4) kesepadanan, (5) kepaduan, dan (6) keparalelan.

\section{Daftar Pustaka}

Akhadiah, S, dkk. 1984/985. Bahasa Indonesia: Kalimat Efektif. Jakarta: Universitas Terbuka.

Arifin, E. Z. dan A. Tasai. 1987. Cermat Berbahasa Indonesia. Jakarta: MSP.

Kemendikbud. 2013. Kurikulum SMP: Silabus Mata Pelajaran Bahasa Indonesia. Jakarta: Kemendikbud.

Keraf, G.. 1980. Komposisi.Ende-Flores: Nusa Indah.

Mulyono, I. 1986. Penyimpangan Berbahasa di dalam Penggunaan Bahasa Indonesia. Bandung: JPBSIFPBS-IKIP.

Munandir, W. dan Mangundiprodjo. 1998. Komunikasi Lewat Satelit. Jakarta: Gramedia.

Razak, A. 1985. Kalimat Efektif: Struktur, Gaya, dan Variasi. Jakarta: Gramedia. Sobur, A. 2016. Semiotika Komunikasi. Bandung: Remaja Rosdakarya.

Soedjito. 1986. Kalimat Efektif. Bandung: Remadja Karya.

Sunarjo dan D. Sunarjo. 1983. Komunikasi dan Retorika. Yogyakarta: Penerbit Liberty. 
Wibowo, W. 2001. Manajemen Bahasa. Widjaja, H.A.W. 2000. Ilmu Komunikasi:

Jakarta: Gramedia Pustaka Utama.

Pengantar Studi. Jakarta: Rineka Cipta. 